\title{
SOCIO-PSYCHOLOGICAL RECORD OF SOUTHERN THAILAND WOMEN: A STUDY ON THE POLITICAL CONFLICTS 1903-2014 OF SOUTHERN THAILAND
}

\author{
Kuwing Baboe ${ }^{1}$ \\ Khairunnas Rajab ${ }^{2}$
}

\begin{abstract}
This is a qualitative study which prioritizes the use of inductive logic in which the categorization and meaning of symptoms, or the construction of reality are derived from a direct interview with women from Southern Thailand. Qualitative research is characterized as a depiction of reality found through interviews specifically in this regard with 340 women, by a snowball sampling technique, which collects data from respondents. It was conducted by interviewing recommended respondents from Thai society who understand the socio-psychological condition of Pattani, Yala, and Narathiwat in order to verify the theory and socio-psychological phenomenon. This research adopts a qualitative method; a descriptive study to assess the impact of the political conflicts in Southern Thailand on its women's sociopsychological conditions. To achieve this goal, researchers sought to analyze, interpret and construct facts, symptoms and events through detailed descriptions and understand meanings contained
\end{abstract}

1 Lecturer, Teachers' Training and Education Faculty, University Palangka Raya, 73111 Kalimantan Tengah, Indonesia, astutimaria.pru@gmail.com

2 Professor, Psychology of Religion at Teachers' Training and Education Faculty UIN Suska Riau HR., 28293 Riau, Indonesia, khairunnasrajab@gmail.com 
in socio-psychological conditions of Southern Thailand women. In order to obtain accurate data, the researchers conducted indepth interviews to identify what really happens based on strict scientific rules and principles on women's socio-psychological condition in encountering political conflict. Southern Thailand women are considered weak and unfit for political activities. This image brings negative effects on development of the sociopsychological condition of the women. They cannot work outside, and as a result, they spend much more time with domestic affairs. They even suffer from stress, depression, psychosis, and psycho neurosis. These women suffer from prolonged trauma due to hostility, conflict, bombings, murder and terrorist acts. Political conflict in Southern Thailand continues endlessly. It makes the social order damaged, interaction disturbed, and domestic violence and divorce rates rise. The conflict harms the mental condition of all parties. However, women suffer more than men do. To ease the conflict, attention to social and psychological aspects should be taken into account. There should be no discrimination of gender. Also, religious leaders, academics, government, and neutral third parties should collaborate to ease the conflict.

Keywords: political conflicts, Southern Thailand, Muslim women, sociopsychological, mental disorder

\section{INTRODUCTION}

Men and women are differentiated by gender identity, natural anatomy, and chemical makeup. Sociologically, men and women are social creatures that live in groups and communities. Social life of women is typically limited. In many societies, males are considered superior. Compared to men, women are at-risk to various kinds of sexual crimes, in particular rape and other forms of sexual abuse.

In the last two decades, feminist groups have advocated several theories that accurately highlight the status of women in social life. Feminists believe that women are equal with men in terms of social rights and also reject the opinion that women have a lower status compared to men. Feminists disagree with the social norms that indulge in the glorification of male domination in most aspects of social life which result in the social marginalization of women.

It is a reality that women are marginalized in many ways. They are still regarded as second-class creatures, half the price of a man, as assistants, dependent on men, and are often treated with rather coarse language. Their 
rights are limited to private areas of life that are very exclusive and marginal. They are discriminated against in almost every aspects of life, such as social, political, economic, and so forth. The life and death of women are determined by others in a patriarchal society. ${ }^{3}$

For instance, the life of Muslim women in the Middle Ages in various regions and periods were governed through patriarchal customs. Regarding marriage, ${ }^{4}$ for the wives of the upper class, polygamy and concubinage are more emotional and psychological problems than an issue of economics. Also, the needs of the concubines may result in economic instability. Thus, security guarantees are obtained by the wives from their husband. 5

Women's status, whether marginalized or not, must manifests itself as a priority in life. ${ }^{6}$ A woman has interest in determining her identity, selfactualization, and a sense of appreciation. The practice of gender discrimination hinders women to achieve their social and self-interests. This practice negatively impacts the lives of women and disallows the from defending their rights. Discrimination against women also contributes to many forms of social maltreatment. In principle, both men and women are the equal in the sight of God. Both are indistinguishable except from gender, age, emotional stability, authoritarianism, intelligence, motivation, and self-esteem. ${ }^{7}$

Gender, whether male or female, is natural and inevitable. Both are characterized by their physical characteristics. The biological anatomical differences of men and women are quite obvious, but they should not be used to classify people's roles in social life. Biological realities that discriminate between genders has spawned two major theories: nature and nurture. Nature theory regards differences in the roles of men and women as natural. As such, anatomical differences between men and women become a major factor in determining their social roles. Men dominate more than women do. Men are regarded as more potent, more powerful, and more productive than women. Pregnancy, childbirth, and breastfeeding are regarded as limitations to women's movement. On the other hand, men are not capable of these actions. These differences thus allocate different functions and responsibilities between men

3 Abdul Moqsit Ghozali et al., Tubuh Seksualitas, dan Kedaulatan Perempuan: Bunga Rampai Pemikiran Ulama Muda (Yogyakarta: LKiS, 2002), xi.

4 Laila Ahmed, Wanita dan Gender dalam Islam: Akar-Akar Historis Perdebatan Modern, terj. MS. Nasrullah (Bandung: Lentera, 2000), 131.

5 Laila Ahmed, Wanita dan Gender dalam Islam: Akar-Akar Historis Perdebatan Modern, 135.

6 See, Maslow's Hierarchy of Needs.

7 Armawati Arbi, Psikologi Komunikasi dan Tabligh (Jakarta: Amzah, 2012), 198. 
and women. Men play a role in the public sector and women are confined to the domestic sector. On the other hand, nurture theory assumes that the roles men and women play are not determined by biological factors, but by the conventions of society. In other words, social roles which are considered the standard and understood as part of religious doctrine, according to this theory, are neither the Will of God nor a product of biological determination, but as a product of social construction. ${ }^{8}$

From the Islamic point of view, men and women are social creatures who share mutual attraction between each other with the love and affection, officiated and made legitimate through marriage. ${ }^{9}$ Through marital relationships, men and women form a small group which is called a 'family'. In a family, a man as a husband is the head of a family and responsible for his family, such as to protect and to feed its members. A woman as a wife plays a role in supporting her husband and to take care of children. By playing these roles, a family is believed to live in a harmony.

Socio-psychologically, men and women have the same desires to meet the needs of their life. Each individual has specific needs or specific motives and behaves in such a way as to maximize the fulfillment of his/her needs. ${ }^{10}$ Individuals need to fulfill physiological, psychological, and spiritual needs appropriately. ${ }^{11}$ The fulfillment of these needs aims to avoid bad influences on physical and mental health.

Humans as a socio-psychological community need peace and harmony in their life. To achieve these, social communities as individuals need to preserve physiological, psychological, and spiritual needs. Because all these needs are essential, individuals have to struggle to fulfill them. If individuals cannot fulfill these needs, they will suffer from physical and mental disorders. ${ }^{12}$

Southern Thailand's political conflicts from the 1903 to 2014 have harmed the socio-psychological condition of women there. They do not live in peaceful conditions and cannot function normally. They cannot meet their physiological, psychological, and spiritual needs well. The conflicts have worsened their physical and mental condition. Both men and women suffer from trauma because of terror, bombing, murder, and intimidation. The effects

\footnotetext{
$8 \quad$ Nasaruddin Umar, Argumentasi Kesetaraan Jender Perspektif al-Qur'an (Jakarta: Paramadina, 2001), xxi.

9 See, QS. al-Rūm 30: 21.

10 David O Sear, Social Psychology (California: Prentice Hall, 1985), 16.

11 M. Utsman Najati, Psikologi dalam Tinjauan Hadits Nabi SAW(Jakarta: Mustaqim, 2003), 22.

12 M. Utsman Najati, Psikologi dalam Tinjauan Hadits Nabi SAW, 25.
} 
Socio-Psychological Record of Southern Thailand Women:

A Study on the Political Conflicts 1903-2014 of Southern Thailand

of the conflicts have led to a crisis of personality and confidence. Thus, these effects harm the family, community, religion, and nation.

In this study, the researchers aim to review the socio-psychological condition of Muslim women in southern Thailand. This research seeks to examine ways in which religious values, in particular Islam, response to issues of gender bias.

\section{LITERATURE REVIEW}

The objective of this study is to review the socio-psychological status of Muslim women in Southern Thailand. In that community, women are struggling to gain and defend their rights. This is the first research initiative to study the influence of religious values and gender-biased practices on Muslim women's psychological conditions. Most previous studies about gender issues were based on secondary data analyses and were primarily from the perspective of the Quran. For example, Nasaruddin Umar ${ }^{13}$ has discussed theories relating to gender and gender concepts in the Quran. Falling into the conventional or typical practice, Nasaruddin's work was based on secondary data. Different from previous studies, this research is the first to examine the aspect of religion on women's socio-psychological conditions via a systematic and scientific social research method, and through invaluable primary data collected directly from the subjects of the study.

Several books and studies regarding Islam in Pattani are available. For instance, Teeuw and Wyatt-Tale of Pattani ${ }^{14}$ (Pattani Story) in 1970 was a comprehensive account about the history of Pattani Muslims and their political conflicts. Another book was Surin Pitsuwan's, Islam in Thailand, Nationalism of Pattani Malay Community. ${ }^{15}$ In this book, Pitsuwan wrote about several important aspects of Pattani Muslim networks, political conflicts, and the role of scholars in the struggle for independence from the government of Thailand in Bangkok.

Even though there are countless books about Islam in Southern Thailand, books or research about the lives of the Muslim women of Southern Thailand, in particular their socio-psychological issues, their rights in politics, their

13 Nasaruddin Umar, Argumen Kesetaraan Jender: Perspektif al-Quran (Jakarta: Paramadina, 1991), 7.

14 Teeuw \& Wyatt, Tale of Pattani (Singapore: n.p., n.d.), 15.

15 Surin Pitsuwan, Islam di Muangthai; Nasionalisme Melayu Masyarakat Pattani (Jakarta: LP3ES, 1989), 3. 
rights to work outside the home, discrimination against them, and their status as the most at-risk gender as victims of crime are scarce. In response to this, we believe that this study is imperative to be carried out to obtain accurate information on the real socio-psychological conditions of Southern Thailand women confronted with political conflict.

\section{RESEARCH METHODOLOGY}

This research adopts a qualitative method; a descriptive study to assess the impact of the political conflicts in Southern Thailand on its women's sociopsychological conditions. This study does not start from a deductive theory, but from empirical facts. Researchers were in Southern Thailand to obtain data. They then recorded, analyzed, interpreted, and drew conclusions based on that data. The research findings in the form of concepts, principles, laws, and theories were established and developed from the data, not from existing theories. This is a qualitative study which prioritizes the use of inductive logic in which the categorization and meaning of symptoms, or the construction of reality are derived from direct interviews with women in Southern Thailand. Qualitative research is thus characterized as a depiction of reality found by interviewing 340 women through a snowball sampling technique, conducted by interviewing recomended respondents who understand the socio-psychological condition of Pattani, Yala, and Narathiwat, in order to verify the theory and socio-psychological phenomenon. ${ }^{16}$

This study aims to reveal the social-psychological phenomenon that exists in Southern Thailand as an effect of political conflict. To achieve this goal, researchers sought to analyze, interpret and construct facts, symptoms and events through detailed descriptions and understanding the meaning contained in the socio-psychological conditions of Southern Thailand women. In order to obtain accurate data, the researchers conducted in-depth interviews to identify what really happens based on strict scientific rules and principles on women's socio-psychological conditions in encountering political conflict.

Political conflicts have occurred since 1903 AD and have resulted in some negative effects, including psychological effects. To explain the psychological reality that is directly felt by women in Southern Thailand, researchers were required to interview a number of women who live in the three areas of conflict,

16 Creswell, John W, Research Design: Qualitative and Quantitative Approaches (California: n.p., 1994), 4-7. 
Socio-Psychological Record of Southern Thailand Women: A Study on the Political Conflicts 1903-2014 of Southern Thailand

namely: Pattani ${ }^{17}$, Yala ${ }^{18}$, and Narathiwat. ${ }^{19}$ For this purpose, researchers conducted random interviews with women in these areas.

\section{HISTORY OF POLITICAL CONFLICT IN SOUTHERN THAILAND}

The first collective reaction to the renewal program in Pattani region occurred in 1903. One year later, the King of Pattani, Abdul Kadir established a reform movement. He implemented a strategy of public resistance to provoke the Thai King. At the same time, he endeavored to get a help from the world, especially the British whom were concerned with Malay Kings in Southern Thailand rejecting the Thai King's . They even ordered subordinates to boycott all meetings held by the Thai authority. The public resistance resulted in significant concerns by the Thai authority because without local assistance at the district and village levels, the reform agenda would not be effective. ${ }^{20}$ Political conflicts in Southern Thailand were also triggered by the persecution of Muslims. Thai Muslims felt persecuted under the pressure of assimilation by the majority, such as the imposition of the use of Thai names.

The Thai authority did not care about feelings of the Malay and religious population. The government tried to destroy the Muslim schools and to replace them with Thai schools. Also, the government sought to destroy the influence of the Malay language among Muslims. The government neglected Islamic celebrations, persecuted, held, and sometimes even killed political and Muslim religious leader. ${ }^{21}$

\footnotetext{
17 Pattani is a conflict region which has an estimated population of 686,186 people and an area of $1.940 \mathrm{~km}^{2}$, https://www.google.com/search?q=jumlah+total+pendu $\mathrm{duk}+$ selatan + thailand\&oq $=$ jumlah + total + penduduk + selatan + thailand\&aqs $=$ chro me..69i57.29296j1j7\&sourceid $=$ chrome\&espv=2\&es_sm=93\&ie $=U T F-8 \# q=$ pen duduk+provinsi+narathiwat, accessed on 9 September 2015.

18 Yala is a conflict region which has an estimated population of 415,537 people and an area of $4.521,1 \mathrm{~km}^{2}$.

19 Narathiwat Yala is a conflict region which has an estimated population of 774, 799 people and an area of $4.475 \mathrm{~km}^{2}$.

20 Surin Pitsuwan, Islam di Muangthai; Nasionalisme Melayu Masyarakat Pattani, 39.

21 Around the year 1973 to 1975 , about five hundred Muslims in Southern Thailand were killed by the Thai authority. The Central government forced the Muslims to take the name of non-Muslim Thai's, in order to dilute their Islamic heritage. See, M. Ali Kettani, The Moslem Minority in the Modern World (Jakarta: King Presindo Persada, 2005), 204.
} 
Muslims in Southern Thailand, ${ }^{22}$ are accustomed to being second-class citizens. Persecution, murder, and discrimination have become part of their lives. Even Muslims who name their babies with Islamic names are intimidated. They are forced to use Thai names instead. Also, educational institutions are nationalized from Islamic schools into Thai schools.

In addition, the political boundaries are not congruent with the limits of ethnic-cultural. The conflict which has lasted more than two hundred years in Southern Thailand is just one example. This conflict seemed to justify the assumption that globalization and the post-Cold War changed shape the nature of conflict. The Cold War period is marked by armed conflicts between countries which by proxy, through lesser nations. After the cold war, conflict is often said to have changed from inter-state conflicts into an internal conflict in countries marked by nationalistic disputes. The conflict in Southern Thailand is not always relevant to this assumption because it has lasted more than two centuries. However, it is believed that the phenomenon of globalization in some ways influenced the Muslim community's struggles in Southern Thailand. ${ }^{23}$

Inter-ethnic and religious conflicts have led to unstoppable political problems that have lasted for years without any obvious solution. The harassment of the Malay language by the Thai authority has triggered discomfort for every Muslim. The number and activity of religious schools are restricted. Muslim scholars and leaders are persecuted and even killed. These issues therefore worsen the conflict resolution process.

The conflicts which have taken place over a long period of time have in fact spawned several pro-Malay Muslim movements in Southern Thailand

22 In contrast to the majority of the Thai people, who are in general Theravada Buddhists, people of Southern Thailand racially included in the class of 'Malay' and the religion of Islam. Religious life is very strong in Southern Thailand, for instance, all the boys should be able to read the Quran, learn Arabic and go to Mecca to perform the Hajj because this is the only way to obtain a high social status. Those who lived in Mecca after performing the Hajj usually return to their hometown and become tokguru (teacher at a boarding school). Children in Southern Thailand are educated in boarding schools, in addition to formal education in schools which are run by the government. Two of these institutions have important implications in social, political, and economic life for the people of Southern Thailand. See, Baig Wardhani, 'Bila Militer Ingkar Janji,' http://baiq-wardhani-fisip.web.unair.ac.id/ artikel_detail-64329-Umum-Konflik\%20Ientitas\%20di\%20Thailand\%20Selatan. html, downloaded on 17 December 2014.

23 Baig Wardhani, 'Bila Militer Ingkar Janji,' http://baiq-wardhani-fisip.web.unair. ac.id/artikel_detail-64329-Umum-Konflik\%20Ientitas\%20di\%20Thailand\%20 Selatan.html, downloaded on 17 December 2014. 
Socio-Psychological Record of Southern Thailand Women: A Study on the Political Conflicts 1903-2014 of Southern Thailand

i.e., Gerakan Rakyat Pattani (Pattani People's Movement, GRP) which was established by Haji Sulong on 3 April 1947. Another movement is the Association of Malay Pattani People in Kelantan which was established on February 1948. This movement was attended not less than 500 people. This movement is the pioneer of the establishment of an organization of Gabungan Melayu Pattani Raya (GEMPAR) that was founded by Tengku Mahmood Mayideen (the youngest son of Tengku Abdul Kadir Kamaruddin). In 1959, Tengku Abdul Jalil bin Tengku Abdul Muttalib established Barisan Islam Pembebasan Pattani (Islamic Liberation Front Pattani, (BIPP). Haji Karim bin Hasan in 1960 founded Barisan Revolusi Nasional (the National Revolutionary Front, BRN). Then in the late 1970s, Nusa Jalil Abdul Rahman founded Barisan Revolusi Nasional Melayu Pattani (the National Revolutionary Front Melayu Pattani, BRN-Congress), and in 1968, Tengku Bira Kota Nila and Kabir Abdul Rahman founded the Pattani United Liberation Organization (PULO). In 1989, Wahyudin Mohammad, the former deputy chairman of the BIPP, established the Pattani Mujahideen Movement (GMP). ${ }^{24}$

Movements and organizations that were established in Southern Thailand are the result of disappointment against the inhumane incidents committed by the Thai authority. The Bangkok government has thus far not been able to be fair in resolving the conflict. This inconvenience brings a negative impact on the Muslim community in Southern Thailand. Conflicts that occur from year to year have gone on for two centuries have put concern in the Muslim community which are the majority in the three provinces of Pattani, Narathiwat, and Yala. Even though the Muslims are the minority in Thailand, some of the provinces are given the autonomy to manage themselve. The same view of the Muslims community to become an autonomous country triggers a struggle that has thus far seen no end.

Armed conflict in Thailand occurred between Thai troops against separatist groups of Southern Thailand. The most dominant and most popular separatist group is Patani United Liberation Organization (PULO), which aims to establish an independent nation "Pattani Darussalam". In general, conflicts in Southern Thailand are divided into three phases based on intensity and time period: the initial phase (1960-1998), the resitance phase (2001-2004), and the critical phase or climax of the conflict (2005-present).

The political condition of Malay Muslims in Southern Thailand is in line with the evolution of the country. The relationship between the center and local government changed when the central government took authority. Under

24 Syaifullah, Sejarah dan Kebudayaan Islam di Asia Tenggara (Yogyakarta: Pustaka Pelajar, 2010), 93. 
absolute monarchy, policies and decisions related to the local government at the final level depend on the discretion of the Thai King. The state affairs have become the king's personal affairs since the Sukhothai period (the 13th century). From a political point of view, the bureaucrats are the servants of the king. The affairs of the king are managed best by himself and his bureaucrats. There is no mechanism to participate or to resolve conflicts between the ruler and the ruled. In such a system, challenges to policies implemented by bureaucrats are considered as a direct challenge to the authority which, according to the bureaucrats, they represent. Thus in an absolute monarchy, the only way to express thoughts is through a rebellion. Although to a certain extent, the integration has been achieved towards the end of the reign of King Chulalongkorn (1910), the Pattani Muslim Malay believed that the rebellion that they have embarked on sporadically remains effective as an expression of their concerns to the central government. ${ }^{25}$

The symptoms of Southern Thailand's Muslim community's discomfort, particularly Pattani against the government of Bangkok, is not something new. Intimidation, hegemony, and impartiality by the central government in Bangkok for Muslims is an unfortunate reality suffered by the Malay Muslims from one generation to the next. Meanwhile, the government of Bangkok continuously pressures the Malay Muslim community.

The Pattani Muslim community have risen to demand their rights since the late 1960s. Many factors support the resistance of the Pattani Muslim community. The first factor is the internal treatment of the central government in Bangkok where the people think the central government does not care about their community. Other factors are the influence of the communist struggle in Indo-China; communists guerillas in the remote areas of Northern Malaysia. All of these factors have motivated Pattani Muslims entirely to rise up against the central government. ${ }^{26}$

Political conflicts in Southern Thailand fluxuate. Some progress has been achieved to solve and ease the conflicts. One of the efforts carried out by the Thai government is to bestow a special autonomy status and some kinds of subsidies to Southern Thailand. However, because the policy is not followed by improvements on the quality of infrastructure, the ongoing peace process does not run well. Also, the Thai government revoked this special status in 2001.

\footnotetext{
25 Surin Pitsuwan, Islam di Muangthai; Nasionalisme Melayu Masyarakat Pattani, 56.

26 Syaifullah, Sejarah dan Kebudayaan Islam di Asia Tenggara, 93.
} 
Socio-Psychological Record of Southern Thailand Women: A Study on the Political Conflicts 1903-2014 of Southern Thailand

From 2001 to 2004, chaos erupted after the special autonomy status was revoked by the Thai government in Bangkok. Some cases of shootings against civilians increased sharply. The targets of these shootings were not only civilians, but also military posts. A mosque became an evidence of these shootings when many militants hiding in them were killed in cold blood on April 28, 2004.

Various efforts have been done to ease the conflicts since 2004. The Thai government has invited stakeholders of Southern Thailand to discuss and to find ways to stop the conflicts. Unfortunely, these efforts to stop the conflicts have not worked well as of yet. The conflict even became worse as a result. The militias of Southern Thailand attacked and executed people who were not with them. They also killed the local religious leaders.

The vigorous activity of the rebels made Thai Prime Minister Thaksin Shinawatra, deploy more military personnel in the conflicted areas. In total, there are about 24,000 soldiers $_{2}$ and nearly 70,000 members of pro-government militias there since 2004. However, the lack of skills of the Thai troops in counter terrorism measures, along with a lack of mutual understanding with the local population made the attempt by the army to quell the conflict ineffective. The army also fought with the local police because of the involvement of some members of the latter in a drug syndicate in Southern Thailand. ${ }^{27}$

More than 6,000 people were killed and more than 10,000 were injured from 2004 to 2014 in the previous ethnic separatist insurgency, which has been taken over by extremist jihadists, and they competed with both Thai Buddhist minorities and local Muslims who have a moderate approach or support the government of Thailand. ${ }^{28}$

\section{THE WOMEN'S SOCIO-PSYCHOLOGICAL RECORD OF SOUTHERN THAILAND}

Political conflicts that have occurred since 1903 AD, in fact, have resulted in some effects, including psychological effects. To explain the psychological reality that is directly felt by women in southern Thailand, researchers required to interview a number of subjects of the women who live in the three areas of conflict, namely: Pattani, Yala, and Narathiwat. For this purpose, researchers conducted random interviews with women in the areas.

\footnotetext{
27 Syaifullah, Sejarah dan Kebudayaan Islam di Asia Tenggara, 93.

28 Wikipedia, http://id.wikipedia.org/wiki/Krisis_Thailand_Selatan, accessed on 17 December 2014.
} 
Before analyzing the results of these interviews, two women were specifically interviewed about the socio-psychological effects of the political conflicts of Southern Thailand. Wasithiyah (anonymous) explained while sobbing that she herself saw a shooting by unknown people against an innocent person at a crossroad. The shooting occurred suddenly and without any noticeable provocation. Wasithiyah saw the victim covered in blood. According to her testimony, no one dared to look at the victim closely. People around the crossroad were very likely to be afraid. Another eye witness, Fauziah (anonymous) seemed to be hesitant to be interviewed. She was afraid that an interview would bring bad impacts on her. However, she eventually agreed to be interviewed and she told that one of her relatives was forcibly abducted and taken to an unknown location.

The interview with the two women made the researchers believe that the women were under a great shock, depressed, and very traumatic. The fact reveals that the political conflict in Southern Thailand has involved innocent Muslim women and brought about misery both physically and mentally.

The researchers began their interviews with a question about the interviewees' knowledge about the conflicts. According to a few of the respondents, the political conflicts started in 2004 and until now have not been resolved. From the researchers' point of view, women in southern Thailand are mostly overshadowed by the tragic events that occurred in the Gersik Sulthan Muzaffar Shah Mosque Pattani in 2004. According to Ustads Burhan (anonymous), one of the Pattani residents involved in the study, a number of Muslims were killed by unknown people. The Muslims who were killed were doing Asr prayers in congregation, as said by Ustads Burhan. ${ }^{29}$

The same question was asked of respondents in Narathiwat and Yala. Similar to their counterpart in Pattani, they informed that political conflicts have taken place since 2004. The incident that occurred during 2004 can be seen as a bitter tragedy that traumatized them. The tragedy of the shooting and murder they saw and heard has brought dangerous impacts on the sociopsychological condition of these women.

Traumatic effects experienced by women in the three provinces of Pattani, Narathiwat, and Yala are a sense of fear, tension, and threats.

When the researchers questioned who were involved in the conflict, the answers given by the respondents varied. Some people replied that soldiers were involved in the conflicts. Some others answered Muslim religious leaders.

29 Burhan (Ustads, Pattani residents), in interview with author, on 23 August 2014. 
If the chronology of conflict is analyzed, so far there is the resistance of the people of Pattani, Narathiwat, and Yala against oppression, injustice, and the deprivation of rights committed by all parties. All of the resistance was done through involving people in established organizations, such as the Patani People's Movement (GRP), Great Malay of Pattani (GEMPAR), Islamic Liberation Front of Pattani (BIPP), Nationalist Revolution (BRN). Pattani Malay National Revolutionary Front (BRN-Congress), Pattani United Liberation Organization (PULO), and Mujahideen Pattani Movement (GMP)..$^{30}$ These organizations initially had the same vision to gain sovereignty in Pattani. However, when the struggle had not ended, their image changed to the struggles of their own respective organizations; their joint efforts were broken by factional interests.

In the researchers' point of view, the different answers that were given by the women to these questions are because their opinions on the political behaviour of each woman is different. Moreover, when a question regarding when a conflict takes places in the three provinces was asked to the Prince of Songkhla University student Fajar (anonymous) ${ }^{31}$ he explains that he does not know the motives and aims of the conflict. He even does not know who trigers the conflict. This uncertainty shows women's doubts on associations that claim their struggle is for the people in these three provinces.

The data of this research also revealed that the "areas of conflict" including Pattani, Narathiwat, and Yala is considered a common phrase for women in three provinces in question. Other provinces, such as Songkhla and Satun are not known as conflict provinces, even though Muslim are the majority population in these regions. This might be due to the fact that political movements or associations were not established during conflicts in these areas.

The political clashes in Southern Thailand have resulted in atrocious impacts on the socio-psychological development of women. An interview with some women of the conflicted provinces Pattani, ${ }^{32}$ Narathiwat, ${ }^{33}$ and Yala, ${ }^{34}$ showed the emergence of feelings of fear, restlessness, phobias, stress, and depression. Women in Pattani, Narathiwat, and Yala feel frightened to leave

30 Syaifullah, Sejarah dan Kebudayaan Islam di Asia Tenggara, 93.

31 Fajar (anonymous), in interview with author on 23 August 2014.

32 Khadijah Bueraheng, Suriyani Yusuf, Ropiah, and others (Women in Pattani), in interview with author on 24 August 2014.

33 Hasanah Chesoh, Arseeyah Sa'i, Wafa Maso, and others (Women in Narathiwat), in interview with author on 25 August 2014.

34 Siti Zarrah, Fauziah, Kautsar, and others (Women in Yala), in interview with author on 26 August 2014. 
the house, because they are worried about unpredictable attacks, bombs, and acts of terror that might occur suddenly. Only a few women are not afraid to leave the house. These women have to go outside due to several reasonss. For example, because they have to make a living, they believe that the conflict is typical. Also, few of them are not worried about going out since thay have a firm belief that God alone determines life or death. Feelings of fear, stress, and depression are a concrete form of traumatic mental attitude. If this traumatic mentality continues to be part of an individual's life, then adverse impacts result in fatal mental shock.

Mental shock such as turmoil, worry, anxiety, stress, and depression are indicators of mental disorder. Mental disorder is the inhibition of synergy between elements of the soul. ${ }^{35}$

Other impacts of the uprising, shootings, bombings and acts of terror result in anxiety for women to participate in political activities, for instance being a general election contestant. In fact, they are even afraid to talk about politics. Interviews with some women in Pattani, Narathiwat, and Yala showed that 30 people who were surveyed in the three conflicted provinces expressed fears of doing political activities. Even when they were questioned with respect to this research, they strongly objected to testify.

Most of the women in Southern Thailand get confused dealing with conflicts that have yet to end. They hope that political conflicts can be resolved as soon as possible. Of the 60 respondents in the three areas of conflict, when being asked about their expectations for the settlement, women said that they never stop praying and all the bombings, terror, murder, and intimidation can be resolved through appropriate means.

Women in the region are very keen to live in peace and harmony. They want to work based on their level of competence, they want to devote themselves to the nation and the country comfortably, and they wish to live with anyone in their daily lives. The anxiety and confusion can only be solved by all parties. With the same dream, vision, mission and dedication to the same homeland, they believe everything will run better. Unfortunately, they worry that agreement among parties involved in the conflicts is hard to achieve. It is because each party have different interests.

However, the women in Southern Thailand suffer from psychological pressure because of the tragic experiences they have gone through. They frequently saw their friends and even their family members shot dead. They

35 Khairunnas Rajab, Obat Hati (Yogyakarta: LkiS, 2010), 8. 


\section{Socio-Psychological Record of Southern Thailand Women: A Study on the Political Conflicts 1903-2014 of Southern Thailand}

just cried hysterically, ${ }^{36}$ seeing their parents, their brother, their sister shot and ending up as a bloodstained body. When some of the correspondents were asked about the tragic events they saw, they were shocked and found it difficult to continue their story. ${ }^{37}$ This indicates that the tragedies were very painful for them.

The researchers believe that the psychological impact and the aforementioned phenomenon are something risky for the women's mental development. The recovery itself is traumatic, ${ }^{38}$ as the women suffer a very long time. They suffer from mental shock and severe depression. ${ }^{39}$

Furthermore, the women can not work very well. They feel anxious all day they work. The women when being interviewed, stated that they could work during the day because of the strict custody and under the protection of military personnel, especially in areas that are prone to acts of terror and murder by unknown persons.

If the acts of terror and intimidation continue, people cannot identify when they are free of terror, bombings, intimidation, and murder. As such, the psychological problems will continue to appear. The psychological problems result in another problem in their family. Psychologically, individuals who suffer from mental disorders can hinder the realization of harmony with their community and environment. ${ }^{40}$

Some of the samples interviewed in Yala showed that most of the disputes taking place are due to psychological stress, trauma, and depression. When respondents were asked whether the stress, trauma, and depression experienced by women were due to the conflict, most of them nodded to express their

36 Sudden screaming, usually appear by causes that are not commonly experienced by an individual.

37 Those interviewed did not want to mention their names, likely due to worries. The interview was conducted on 20 September 2014.

38 Trauma is an experience that comes on suddenly and surprisingly. It brings bad impacts on an individual's psychological condition.

39 Depression is a condition that is more than a sad state. When a depressed person's condition results in disruption of daily social activities, it is called Depression Disorder. Some symptoms of depression are feelings of sadness disorders, excessive tiredness after doing usual routines, loss of interest and passion, reluctant to move, and disruption of sleep patterns. Depression is one of the main causes of suicide. See, http://id.wikipedia.org/wiki/Depresi_\%28 psychology\% 29, accessed on 25 December 2014.

40 Zakiah Darajat, Kesehatan Mental (Jakarta: Bulan Bintang, 1986), 132. 
agreement. However, they explicitly did not state that conflicts which occur in their family were due to the political conflicts in the three provinces. ${ }^{41}$

Southern Thailand women in regards to political rights do not take part in parliament. It is very possible that this area is dominated by men so men play stronger roles there.

Psychologically, turmoil, rebellion, and political conflicts in Southern Thailand bring severe negative impacts on the survival and mental health of women. They suffered traumatic and depression because of the violence they've seen. Hence, the Thai government should be more intensive to find ways so that the conflicts do not take place again in the future.

In addressing the political conflict of Southern Thailand, theological issues, such as faith in peace and $q a d r$, can affect the socio-psychological mindset of women. For instance, Ash'ariyyah theology interprets kasb (an effort) an endeavour, which are very important to obtain a positive outcome. Whatever the benefits received from such business, is to be the power of God, and man is only tawakkal. With this belief, a Muslim woman of Southern Thailand felt the political conflicts are a part of life that must be overcome with a strong determination and confidence in an all-powerful force, which is God Almighty.

Psychologically, behaviour can stimulate conscious motivations into doing something. However, individuals need to do something, rather than just leave the results to God. Tawakkal means to relieve emotional feeelings about God, instead of speculating individuals with beliefs like these can say that their struggles are a matter of destiny. ${ }^{42}$

\section{CONCLUSION}

Southern Thailand is a Muslim region that is characterized by the prior presence of Muslim merchants in Pelabuhan Pattani around the fifteenth century. Since King Tu Antara embraced Islam, the Islamic empire stood sturdily under the reign of Pattani Kings, namely: Sultan Muzaffar Shah (1540), Sultan Shah Manzur (1564), Sultan Patik Siam (1572), Sultan Bahdur (1573), Ratu Raja Hijau (1584), Ratu Raja Biru (1616), Ratu Raja Ungu (1624), and Ratu Raja Kuning (1636).

\footnotetext{
41 Fauziah, Bueraheng, Aishah, and others (Housewives in Yala), in interview with author on 24 August 2014.

42 Khairunnas Rajab \& Wan Muhammad Fariq, 'Psikologi Qadha' dan Qadar,' Jurnal Hadhari, 6/1 (2014): 23.
} 


\section{Socio-Psychological Record of Southern Thailand Women: A Study on the Political Conflicts 1903-2014 of Southern Thailand}

Due to the reform and wishes of the people of Pattani, Narathiwat, and Yala to be independent and autonomous, movements have grown from this since 1903. The reform movement was coordinated by King Pattani, Abdul Kadir. Abdul Kadir took a two-pronged strategy: a public resistance for the sake of provoking a repressive reaction from the Thai ruler. The strategy was expected to trigger a great uprising against the new system. At the same time, attempts were carried out to ask for foreign interference, especially from the UK, who at that time put great attention on Malay lands. At first, the king of Southern Thailand did not obey orders to hand his authority over. Then, he ordered his subordinates to boycott all meetings held by the Thai authorities, which in turn resulted in them asking him to resign. The public resistance made Thai authorities concerned because without local assistance at the district and village levels, the reform agenda would not be effective. The biggest problem that the Thai authority had was that they could not speak Malay.

Political conflicts in Southern Thailand were also triggered by the persecution of Muslims. Thai Muslims felt persecuted and under the pressure of assimilation by the majority, such as the imposition of the use of Thai names. Thai authority did not pay attention to the feelings of Malay nationalism and the religious population. The government tried to destroy the Muslim schools and replace them with Thai schools. Also, the government attempted to destroy the influence of the Malay language over Muslims. The government neglected the celebrations in Islam, persecuted, held, and sometimes even killed political and religious leaders of Muslims.

Since 2004, various kinds of attempts to cope with the conflict has been offered to the Thai government; talks and negotiations with the provinces involved in the conflict continue to be rolled out. However, these efforts have not shown positive results. Bombings and terror have not stopped. Along with bombings, the rebel militias also increasingly do acts of shooting and beheading people who disagree with them, including the local religious leaders.

This research was conducted in Southern Thailand, namely in Pattani, Narathiwat, and Yala in which conflicts take place. Interviews were conducted with the assumption that the conflicts result in a socio-psychological impact on women in the region. Data collected shows that women in the three regions do not live in harmony and even suffer from mental disorders.

In politics, women's activities are limited by the cultural, sociological, and psychological values. Most of the women interviewed do not know about the role of Muslim women in politics and parliament.

There are some cases in the interview with women working as a housewife. They told the researchers that political conflict brought negative impacts 
on them. The tragic events, murder, and shootings have resulted in mental disorders such as trauma, stress, and depression. These mental disorders trigger inharmony in their family.

The facts above reveal that political conflicts have continue since 1960 and have caused harm both physically and psychologically. Women in Pattani, Narathiwat, and Yala are not able to live life as they should. Tragedies and incidents as the impact of political conflict have made them lose children, siblings, friends, and even their parents. These tragedies and facts make the women live in turmoil, restlessness, discomfort, and insecurity which in turn result in stress, depression, and trauma that they suffer for a very long period of time.

\section{RECOMMENDATIONS}

1. Political conflict in Southern Thailand should be resolved by many parties. They are government, non-government organization, community leaders, and academicians.

2. In the settlement of the conflict, the parties involved in the negotiations should consider the socio-psychological aspects of women when a decision is taken.

3. There should be one vision between the Thai government and the nongovernment organizations towards achieving peace.

4. There should be continuous attempts to establish awareness of all elements of society to make peace.

5. The government should be able to get respect from the public, meaning that the government is not partial and discriminatory.

\section{REFERENCES}

Abdul Moqsit Ghozali et al., Tubuh Seksualitas dan Kedaulatan Perempuan: Bunga Rampai Pemikiran Ulama Muda (Yogyakarta: LKiS, 2002) .

Aji Raksa, 'Perkembangan Terakhir di Burma,' http://ajiraksa.blogspot. com/2012/06/perkembangan-kontemporer-islam-di.html, accessed on 16 December 2014.

Armawati Arbi, Psikologi Komunikasi dan Tabligh (Jakarta: Amzah, 2012).

Baig Wardhani, 'Bila Militer Ingkar Janji,' http://baiq-wardhani-fisip.web. unair.ac.id/artikel_detail-64329-Umum konflik\%20IeEntitas\%20di\%20 Thailand\%20Selatan.html, accessed on 17 December 2014. 
Socio-Psychological Record of Southern Thailand Women: A Study on the Political Conflicts 1903-2014 of Southern Thailand

Baig Wardhani, 'Sejarah Konflik Berdarah di Thailand Selatan,' http://republiktawon.blogspot.com/2012/02/sejarah-konflik-berdarah-di-thailand.html accessed on 17 December 2014.

Creswell, John W, Research Design: Qualitative and Quantitative Approaches (California: n.p., 1994).

David O Sear, Social Psychology (California: Prentice Hall, 1985).

Forum Kajian Muslimah Kuwait al-Husna, 'Perkembangan Islam di Thailand,' http://alhusnakuwait.blogspot.com/2012/11/perkembangan-islam-dithailand.html, accessed on 15 December 2014.

Khairunnas Rajab, Obat Hati (Yogyakarta: LkiS, 2010).

Khairunnas Rajab \& Wan Muhammad Fariq, 'Psikologi Qadha' dan Qadar,' Jurnal Hadhari, 6/1 (2014).

Laila Ahmed, Wanita dan Gender dalam Islam: Akar-akar Historis Perdebatan Modern, trans. MS. Nasrullah (Bandung: Lentera, 2000).

M. Utsman Najati, Psikologi dalam Tinjauan Hadits Nabi SAW (Jakarta: Mustaqim, 2003).

M. Ali Kettani, The Moslem Minority in the Modern World (Jakarta: King Presindo Persada, 2005).

Nasaruddin Umar, Argumentasi Kesetaraan Jender Perspektif al-Qur'an (Jakarta: Paramadina, 2001).

Pemuda Muslim Indonesia, 'Sedikit Sejarah Pattani,' http://pmi-sumedang. blogspot.com/2012/02/sedikit-sejarah-pattani.html, accessed on 16 December 2014.

Syaifullah, Sejarah dan Kebudayaan Islam di Asia Tenggara (Yogyakarta: Pustaka Pelajar, 2010).

Surin Pitsuwan, Islam di Muangthai; Nasionalisme Melayu Masyarakat Pattani (Jakarta: LP3ES, 1989).

Teeuw \& Wyatt, Tale of Pattani (Singapore: n.p., n.d.).

Zakiah Darajat, Kesehatan Mental (Jakarta: Bulan Bintang, 1986).

Wikipedia, http://id. wikipedia.org/wiki/psikologi downloaded on 6 March 2012.

Wikipedia, http://id.wikipedia.org/wiki/Provinsi Pattani, accessed on 16 December 2014.

Wikipedia, http://id.wikipedia.org/wiki/Krisis_Thailand_Selatan, accessed on 17 December 2014.

Wikipedia, http://id.wikipedia.org/wiki/Depresi_\%28psikologi\%29, accessed on 25 December 2014. 


\section{Interview}

Burhan (Ustads, Pattani residents), in interview with author, on 23 August 2014.

Fajar (anonymous), in interview with author on 23 August 2014.

Fauziah, Bueraheng, Aishah, and others (Housewives in Yala), in interview with author on 24 August 2014.

Hasanah Chesoh, Arseeyah Sa'i, Wafa Maso, and others (Women in Narathiwat), in interview with author on 25 August 2014.

Khadijah Bueraheng, Suriyani Yusuf, Ropiah, and others (Women in Pattani), in interview with author on 24 August 2014.

Siti Zarrah, Fauziah, Kautsar, and others (Women in Yala), in interview with author on 26 August 2014. 